\section{Public health impact and medical consequences of earthquakes}

\author{
M. R. Naghii ${ }^{1}$
}

Key words: earthquake; risk factors; injuries; mortality, prevention and control.

University of Medical Sciences, Tehran, Iran. All correspondence should be sent to this author at: No. 25, Bank Meli Alley, South Madjidieh St., Tehran, Iran. P/C 16336. E-mail: mrnaghii@yahoo.com
Worldwide, more than one million earthquakes occur each year, an average of about two every minute (1). Research indicates a $60 \%$ probability that an earthquake of Richter magnitude 7.5 or greater will occur on the San Andreas fault in southern California within the next 30 years, and a $50 \%$ probability that an earthquake of 7.0 or greater magnitude will occur on the San Andreas or Hayward faults in the San Francisco Bay region within the same time period (2). As previewed by the significant damages resulting from the 1989 Loma Prieta earthquake in northern California (magnitude 7.1) and the 1994 Northridge earthquake in southern California (magnitude 6.8), the impact of the predicted higher magnitude earthquakes in California and the central United States could potentially kill and injure thousands of people, result in billions of dollars in property loss, and cause severe disruptions to the United States economy (3). Despite remarkable scientific progress in seismology and earthquake engineering during the past several years, achieving high standards of safety against earthquakes is a goal that has yet to be achieved in many parts of the world.

During the past 20 years, earthquakes alone have caused more than a million deaths worldwide (4). Nine countries (Armenia, Chile, China, Guatemala, Iran, Italy, Japan, Peru, and Turkey) account for more than $80 \%$ of all fatalities in this century, and almost half of the total number of earthquake casualties in the world during this period have occurred in China alone (5). Recently, fast urbanization in other seismically active parts of the world whose population densities reach 20000 to 60000 inhabitants per square kilometer makes such areas vulnerable to similarly catastrophic numbers of earthquake-related deaths and injuries. In just the past 10 years, the world has witnessed four catastrophic earthquakes resulting in great loss of life: in Mexico in 1985 (10 000 deaths); in Armenia in 1988 (25 000 deaths); in Iran in 1990 (40 000 deaths); and in India in 1993 (10 000 deaths) (Table 1) (4). The United States has been somewhat fortunate; it has had relatively few earthquake-related casualties so far; only an estimated 1600 deaths have been attributed to earthquakes since colonial times, with over $60 \%$ of these having been recorded in California (6). The number of casualties caused by an earthquake will depend on its magnitude, its proximity to an urban center, and the degree of earthquake disaster preparedness and mitigation measures implemented in the urban center closest to where the earthquake takes place. 
TABLE 1. Twentieth-century earthquakes that caused more than 10000 casualties

\begin{tabular}{clr}
\hline Year & Location (Richter magnitude) & Deaths $^{\mathrm{a}}$ \\
\hline 1985 & Mexico City, Mexico (8.1 \& 7.3) & 10000 \\
1993 & Maharashtra, India (6.4) & 10000 \\
1960 & Agadir, Morocco (5.9) & 12000 \\
1968 & Dasht-i-Biyaz, Iran (7.3) & 12000 \\
1962 & Buyin Zahra, Iran (7.3) & 12000 \\
1917 & Bali, Indonesia (7.0) & 15000 \\
1978 & Tabas, Iran (7.7) & 18000 \\
1905 & Kangra, India (8.6) & 19000 \\
1948 & Ashkabad, USSR (7.3) & 19000 \\
1974 & Chao-T'Ung, China (6.8) & 20000 \\
1976 & Guatemala City (7.5) & 23000 \\
1988 & Armenia, USSR (6.9) & 25000 \\
1935 & Quetta, Pakistan (7.5) & 25000 \\
1923 & Concepcion, Chile (8.3) & 25000 \\
1939 & Chillan, Chile (8.3) & 28000 \\
1915 & Avezzano, Italy (7.5) & 33000 \\
1939 & Erzincan, Turkey (8.0) & 33000 \\
1990 & Manjil, Iran (7.7) & 35000 \\
1927 & Tsinghai, China (8.0) & 41000 \\
1908 & Messina, Italy (7.5) & 58000 \\
1970 & Ankash, Peru (8.3) & 67000 \\
1923 & Kanto, Japan (8.3) & 143000 \\
1920 & Kansu, China (8.5) & 235000 \\
1976 & Tangshan, China (7.8) & 243000 \\
\hline Total: & & 1161000 \\
& &
\end{tabular}

a Rounded off to the nearest thousand.

\section{FACTORS AFFECTING EARTHQUAKE OCCURRENCE AND SEVERITY}

Earthquakes tend to occur in particular zones on the earth's surface that coincide with the boundaries of the tectonic plates into which the earth's crust is divided. As the plates move relative to each other along the plate boundaries, they tend not to slide smoothly but to become interlocked. This interlocking causes deformations in the rocks on either side of the plate boundaries, with the result that stresses build up. As the rocks deform on either side of the plate boundary, they store energy in enormous amounts, given the huge volumes of rocks involved. When the fault ruptures, the energy stored in the rocks is released in a few seconds-partly as heat and partly as shock waves, and it is these waves that constitute the earthquake (7). The resultant vibration energy is then transmitted through the earth and, when it reaches the surface, it may cause damage to structures and their collapse, which in turn may injure or kill their occupants.

Magnitude and intensity are two measures of the strength of an earthquake that lay people frequently confuse. The magnitude of an earthquake is a measure of actual physical energy release at its source as estimated from instrumental observations. A number of magnitude scales are in use. The oldest and most widely used is the Richter magnitude scale, developed by Charles Richter in 1936. Although the scale is open-ended, the strongest earthquake recorded to date has been of Richter magnitude 8.9 (8).

On the other hand, intensity is a measure of the felt or perceived effects of an earthquake rather than of the strength of the earthquake itself. It is a measure of how severe the tremor was at a particular location. Thus, whereas magnitude refers to the force of the earthquake as a whole (i.e., an earthquake can have just one magnitude), intensity refers to the felt effects of an earthquake at a particular site. The intensity is usually strongest close to the epicenter of the earthquake and is weaker as one moves away from the epicenter. Intensity is classified on a scale according to the degree of shaking perceived. The intensity in a particular location is determined on the basis of the visible consequences left by the earthquake, such as the extent of the damage to buildings, monuments, pipelines, railroads, bridges, etc., and from subjective reports by people who experience the tremor. The extent of an earthquake is more germane to its public health consequences than its magnitude. Intensity scales also allow comparison with earthquakes that occurred before the development of seismic monitoring instruments.

The destruction that an earthquake causes is a function of its intensity and of the resistance of structures to seismic damage. Four human activities or consequences of human activities have been known to induce earthquakes: (1) the filling of large water impoundments; (2) deep well injection; (3) underground explosions of nuclear devices, and (4) the collapse of underground mine workings. Some have speculated that nuclear detonation along a fault may release strain in a controlled fashion and prevent a major earthquake, but the potential liability of such an experiment gone awry has discouraged even the most intrepid seismic investigators (9).

\section{PUBLIC HEALTH IMPACT AND CLINICAL CONSEQUENCES}

In most earthquakes, people are killed by mechanical energy as a direct result of being crushed by falling building materials. Deaths resulting from major earthquakes can be instantaneous, rapid, or delayed (10). Instantaneous death can be due to severe crushing injuries to the head or chest, external or internal hemorrhage, or drowning from earthquake-induced tidal waves (tsunamis). Rapid death occurs within minutes or hours and can be due to asphyxia from dust inhalation or chest compression, hypovolemic shock, or environmental exposure (e.g., hypothermia). Delayed death occurs within days and can be due to dehydration, hy- 
pothermia, hyperthermia, crush syndrome, wound infections, or postoperative sepsis $(11,12)$. As with most natural disasters, the majority of people requiring medical assistance following earthquakes have minor lacerations and contusions caused by falling elements, like pieces of masonry-roof tiles and timber beams (13). The next most frequent reason for seeking medical attention are simple fractures not requiring operative intervention (14). Such light injuries usually require only outpatient treatment and tend to be much more common than severe injuries requiring hospitalization. For example, after the 1968 earthquake south of Khorasan, Iran, only $368(3.3 \%)$ of 11254 people injured required inpatient care (15). A similar pattern of injuries is discussed in reports by Durkin et al., which indicated that following the 1989 Loma Prieta earthquake in California as many as $60 \%$ of those with earthquake-related injuries either treated themselves or received treatment in non-hospital settings (16). These findings suggest that a substantial number of earthquake-related injuries are treated outside the formal health care system.

Major injuries requiring hospitalization include skull fractures with intracranial hemorrhage (e.g., subdural hematoma); cervical spine injuries with neurologic impairment; and damage to intrathoracic, intraabdominal, and intrapelvic organs, including pneumothorax, liver lacerations, and ruptured spleen. Most seriously injured people will sustain combination injuries, such as pneumothorax in addition to an extremity fracture. More detailed inpatient information is available from data collected on 4832 patients admitted to hospitals following the 1988 earthquake in Armenia. Consistent with findings from other major earthquakes, these data show that combination injuries constituted $39.7 \%$ of the cases. Superficial trauma such as lacerations and contusions were the injuries most frequently observed $(24.9 \%)$, followed by head injuries (22\%), lower extremity injuries (19\%), crush syndrome $(11 \%)$, and upper extremity trauma (10\%) (17). Hypothermia, secondary wound infections, gangrene requiring amputation, sepsis, adult respiratory distress syndrome (ARDS), multiple organ failure, and crush syndrome have been identified as major medical complications in past earthquakes. Crush syndrome results from prolonged pressure on limbs causing disintegration of muscle tissue (rhabdomyolysis) and release of myoglobin, potassium, and phosphate into the circulation (18). Systemic effects include hypovolemic shock, hyperkalemia, renal failure, and fatal cardiac arrhythmias. Patients with crush syndrome may develop kidney failure and require dialysis (19). Following the 1988 earthquake in Armenia, more than 1000 victims trapped in collapsed buildings developed crush syndrome as a result of limb compression; 323 developed secondary acute renal failure requiring renal dialysis (20). Am- putations and chronic sequelae of orthopedic and neurologic injuries, especially spinal cord injuries, can be expected (21). For example, a rate of 1.5 cases of paraplegia per 1000 persons injured was observed after the Guatemalan earthquake (22) of 1976, and more than 2200 people became paraplegics as a result of injuries sustained in the 1976 quake in Tangshan, China (5). Following the Tangshan earthquake, all these chronically disabled people required extensive treatment and rehabilitation in long-termcare facilities, resulting in a significantly taxed health care system in the region for years to come.

As noted above, trauma caused by the collapse of buildings produces the majority of deaths and injuries in most earthquakes (4). However, a surprisingly large number of patients require acute care for non-surgical problems, such as acute myocardial infarction, exacerbation of chronic diseases such as diabetes or hypertension, anxiety and other mental health problems such as depression $(23,24)$, respiratory injury caused by exposure to dust and asbestos fiber from rubble, and near drowning caused by flooding from broken dams. An example of the adverse health effects of an earthquake was observed in 1981 after a magnitude 6.7 earthquake in Athens, Greece. A 50\% increase in deaths due to myocardial infarction was documented during the first three days after the earthquake, with the death rate peaking on the third day $(25,26)$. There may be a plausible biological mechanism for increased risk of cardiac problems after a natural disaster: emotional stress and physical activity cause increased levels of catecholamines, vasoconstriction, and increased coagulability of the blood (27). If stress has such an acute physiological effect, then the proportion of sudden deaths might be expected to increase. On September 19, 1985, the date of a strong Mexico City earthquake, the number of abortions, premature births, and normal deliveries in chronic care facilities rose and together constituted the primary cause of all admissions seen on that day (14, 28). Even more admissions for these causes occurred four days later, again probably because of the effects of stress related to the disaster (28).

Huge amounts of dust are generated when a building is damaged or collapses, and dust clogging the air passages and filling the lungs is a major cause of death for many building-collapse victims (5, 29, 30). Fulminant pulmonary edema from dust inhalation may also be a delayed cause of death (31). Dust has hampered rescue and clean-up operations by causing eye and respiratory-tract irritation. Burns and smoke inhalation from fires used to be major hazards after an earthquake. For example, following the 1923 earthquake in Tokyo, Japan, more than 140000 people perished, principally because of fires that broke out in a city where most buildings were constructed from highly flammable paper (shoji) and wood material. Since 1950, however, the incidence of 
burns in the aftermath of earthquakes has decreased considerably (4) largely because of engineering interventions, improved standard construction practices, and the use of safer building materials.

Most earthquakes are followed by many aftershocks, some of which may be as strong as the main shock itself. Many fatalities and serious injuries occurred from a strong aftershock that followed two days after the 1985 Mexico City earthquake that killed an estimated 10000 people (28). In some cases landslides may be triggered by an aftershock, after having been primed by the main shock. Some major debris flows start slowly with a minor trickle and then are triggered in waves. In these cases there may be sufficient warning to allow a community that is aware of this hazard to evacuate in time. Local weather conditions, which are known to affect survival time among people trapped in collapsed buildings after an earthquake, have a major influence on the percentage of those injured who subsequently die before they can be rescued.

Our modern industrial cities are laden with chemical and petroleum products that could contribute substantially to the generation of toxic substances following an earthquake (32). Industrial storage facilities for hazardous materials might explode or leak, and damage to a nuclear power plant could lead to widespread contamination by radioactive materials. In a major earthquake, pipelines carrying natural gas, water, and sewage can be expected to be disrupted. Following the Loma Prieta earthquake, about $20 \%$ of post-earthquake injuries were caused by toxic materials (16). Thus, rescue personnel must constantly observe all safety precautions to protect themselves from injury (33).

In earthquakes, people over 60 years of age are at increased risk for death and injury and can have a death rate five times higher than that of the rest of the population. Children between 5 and 9 years of age, women, and the chronically ill also seem to be at an elevated risk for injury and death (34). Lack of mobility to flee collapsing structures, inability to withstand trauma, and exacerbation of underlying disease are factors that may contribute to the vulnerability of these groups. Mortality distribution by age will also be affected to a certain degree by the social attitudes and habits of different communities. For example, in some societies young children sleep close to their mothers and may be more easily protected by them. As might be expected, entrapment appears to be the single most significant factor associated with death or injury. In the 1988 Armenia earthquake, death rates were 67 times higher and injury rates more than 11 times higher for people who were trapped than for those who were not. In general, the morbidity and mortality rates are significantly greater among people who are indoors than among those who are outdoors when the tremor begins (29). Although the probability of finding live victims diminishes very rapidly with time, entrapped people have survived for many days. People have been rescued alive 5, 10, and even 14 days after an earthquake (35), and these "miracle rescues" are often the result of exceptional circumstances. For example, someone with very light injuries could be trapped in a void deep in the rubble with air and possibly water available.

\section{PREVENTION AND CONTROL MEASURES}

Prevention and control efforts need to be multidisciplinary and should include public education programs, as well as better building design and improved quality of construction in those areas most likely to suffer an earthquake (36). The problem of "earthquake casualties" involves questions of seismology, with careful delineation of areas having a high seismic risk; the engineering of the built environment; the nature of both the physical and the sociological environments; aspects of personal and group psychology and behavior; short- and longterm economic issues, as well as many planning and preparedness aspects. Public-health and disasterresponse officials need to work together in the effort to develop and maintain effective seismic safety planning and earthquake mitigation programs (37).

Avoiding unnecessary residential and commercial construction on or near active faults and in areas subject to tsunamis or landslide slope failures, soil liquefaction, and rock falls is technically a secondary prevention measure for earthquakes, but it is a primary prevention measure for earthquakerelated injuries (38). Disaster response to earthquakes is more akin to medical treatment than to prevention, but some aspects of the response may be likened to tertiary prevention in that those responding seek to limit further injury and to control the secondary effects of the earthquake (36). Prompt rescue should improve the outcome of victims, and early medical treatment should lessen the sequelae of the primary injuries (e.g., wound complications, chronic neurological disabilities). Provision of adequate food, water, and shelter should especially help people in vulnerable age groups and those with pre-existing diseases. Effective environmental control measures should prevent secondary environmental health problems, such as gas leaks, fallen or loose wires, damaged appliances and pipelines, sewage backup, and water contamination. Identification and control of long-term hazards (e.g., asbestos in rubble) should reduce chronic health effects. Because rapid rescue of trapped victims and prompt treatment of those with life-threatening injuries can improve their outcome, early rapid assessment of the extent of damage and injuries is needed to help mobilize resources and direct them to where they are most needed (39). Unfortunately, 
the very factors likely to cause large numbers of injuries are also likely to disrupt communications and transportation and to damage medical-care facilities. Public health officials need to establish in advance how the affected areas will be surveyed. Just as speed is required for effective search and extrication, it is also essential for effective emergency medical services, since the greatest demand occurs within the first 24 hours (29).

Unconscious patients with either upper airway obstruction or inhalation injury or any patients with correctable hypovolemia resulting from hemorrhage or burns would be especially likely to benefit from early medical intervention. Safar, studying the 1980 earthquake in southern Italy, concluded that $25 \%$ to $50 \%$ of victims who were injured and died slowly could have been saved if life-saving first aid had been rendered immediately (40). Injured people usually sought emergency medical attention only during the first three to five days following the earthquake, after which hospital casemix patterns returned almost to normal. From the sixth day onward, the need for emergency medical attention declined rapidly and the majority of the wounded required only ambulatory medical attention, so that specialized field hospitals arriving one week or more after an earthquake are generally too late to help during the emergency phase.

The medical and public health impacts of a severe earthquake may well be compounded by significant damage to medical facilities, hospitals, clinics, and supply stores within the affected area (41). In the worst-case scenario, a hospital building may itself be damaged by the earthquake, and the hospital staff may have to continue emergency treatment without using the buildings (42). Hospital emergency plans in earthquake areas should provide for the contingency of evacuating patients from the wards; safely removing critical equipment from operating theaters, radiology departments, and other parts of the hospital; and re-establishing routine patient-care services (43).

\section{CONCLUSION}

Few earthquakes have been adequately studied epidemiologically. Thus, it is vital that plans for follow-up epidemiologic study be developed before an earthquake occurs so that initial surveillance data collected will allow proper follow-up (44). Disaster-response officials must be convinced to invest time and resources in the initial surveillance effort, even though their attention is likely to be focused on emergency medical services and disaster relief. Without this investment, the opportunity to learn many lessons useful for future earthquakes may be lost $(45,46)$. Knowledge ob- tained from different disciplines should be integrated. Most earthquake casualty studies have addressed the problem from the point of view of a single discipline, either that of engineers or that of health researchers. This lack of active collaboration between workers from different disciplines has been a major shortcoming of past research into the health effects of disasters. Successful epidemiologic studies will require close interdisciplinary collaboration among structural engineers, physicians, and epidemiologists. Again, it is important to recognize that earthquakes will recur and that lessons learned during the surveillance effort following a particular earthquake can help save lives during subsequent earthquakes.

\section{SINOPSIS}

\section{Impacto sanitario y consecuencias médicas de los terremotos}

Un terremoto de gran magnitud en una zona urbana es uno de los peores desastres naturales que pueden ocurrir en ciertas partes del mundo. La mayor parte de las medidas aplicables para mitigar los traumatismos tienen que implantarse antes de que el desastre ocurra. Los investigadores han identificado algunos factores de riesgo importantes en relación con las heridas que se asocian, de un modo directo o indirecto, con los terremotos. Como el colapso estructural es el factor de riesgo individual más importante, la seguridad antisísmica debe ocupar un lugar priotario en el uso del terreno y en el diseño y construcción de edificios seguros.

Para poder entender mejor los tipos de traumatismos ocasionados por los terremotos, es indispensable que se integren los estudios epidemiológicos con los de otras disciplinas, tales como la ingeniería, la arquitectura, las ciencias sociales y la medicina. Es esencial, además, tener un mejor conocimiento epidemiológico de los factores de riesgo de morir o de sufrir distintos tipos de heridas y enfermedades como consecuencia de los terremotos a fin de poder determinar qué materiales, instrumental y personal se necesitan para responder de manera eficaz. En zonas propensas a los desastres, el adiestramiento y la educación en primerios auxilios y métodos de rescate debe ser parte integral de todo programa comunitario de respuesta a emergencias y desastres. Lamentablemente, entre terremotos de gran magnitud transcurren períodos relativamente largos, con el resultado de que las autoridades sanitarias se enfrentan al reto especial de tener que comunicarle eficazmente al público los peligros planteados por los terremotos y la necesidad de planificar acciones y emprenderlas antes de que ocurra el siniestro.

Pese a los grandes adelantos científicos que se han producido en seismología e ingeniería antisísmica en años recientes, lograr que se adopten normas estrictas de seguridad antisísmica es una meta que aún no se ha alcanzado en muchas partes del mundo.

Palabras clave: Terremoto, factores de riesgo, traumatismos,mortalidad, prevención y control 
1. Hays WW. Perspectives on the International Decade for Natural Disaster Reduction. Earthquake Spectra. 1990;6: 125-43.

2. Perez E, Thompson P. Natural hazards: causes and effects: Earthquakes. Prehosp Disaster Med. 1994;9:260-71.

3. U.S. Geological Survey. Scenarios of possible earthquakes affecting major California population centers, with estimates of intensity and ground shaking. Menlo Park, CA: USGS; 1981. (Open-File Report 81-115.)

4. Coburn A, Spence R. Earthquake protection. Chichester, UK: John Wiley \& Sons Ltd.; 1992

5. Chen Y, Tsoi KL, Chen F, Kam-Ling T, Gao Z, Zou Q. The Great Tangshan earthquake of 1976: an anatomy of disaster. Oxford, UK: Pergamon Press; 1988.

6. U.S. Department of Commerce, National Oceanic and Atmospheric Administration, and U.S. Department of Interior, Geological Survey. Earthquake history of the United States. Rev. ed. with supplement for 197140. Boulder, CO: USDC, USDI; 1982. (Pub. No. 41-1).

7. Perez E, Thompson P. Natural hazards: causes and effects. Earthquakes. Prehosp Disaster Med. 1994;9:260-71.

8. California Department of Commerce, Division of Mines and Geology. How earthquakes are measured. California Geol. 1979:32 (Feb.):35-7.

9. Stratton JW. Earthquakes. In: Gregg $\mathrm{MB}$, ed. The public health consequences of disasters. Atlanta: Centers for Disease Control; 1989. Pp. 13-24.

10. Pretto E, Safar P. Disaster reanimatology potentials revealed by interviews of survivors of five major earthquakes. Prehosp Disaster Med. 1993;8:S139.

11. Pretto EA, Angus DC, Abrams JI, Shen B, Bissell, Ruiz Castro VM, et al. An analysis of prehospital mortality in an earthquake. Prehosp Disaster Med. 1994;9:107-24

12. Mikaelyan AL, Belorusov O, Lebedeva RN, Buniatian AA, Efuni SN, Shbalin AI, et al. The experience of the All-Union Surgery Scientific Center of the USSR Academy of Medical Sciences and its branch in the treatment of the Armenian earthquake victims. In: Proceedings of the International Conference on Disaster Medicine, Moscow 22-23 May 1990. Moscow: Ministry of Health; 1990; 1:467.

13. Jones NP, Noji EK, Smith GS, Krimgold F. Preliminary earthquake injury epidemiology report: In: Bolin R, ed. The Loma Prieta earthquake: studies of short-term impacts. A Natural Hazards Center monograph. Boulder, CO: University of Colorado; 1990. Pp. 33-43.

14. Malilay JM. Comparison of morbidity patterns in two hospitals following the September 19, 1985 earthquake in Mexico City. Washington, D.C.: Pan American Health Organization; 1986.

15. Memarzadeh P. The earthquake of $\mathrm{Au}-$ gust 31, 1968, in the south of Khorasan, Iran. In: Proceedings of the Joint IHF/ IUA/UNDRO/WHO Seminar. Manila:
World Health Organization Regional Office; 1978. P. 13.

16. Durkin ME, Thiel CC, Schneider JE, De Vrient $T$. Injuries and emergency medical response in the Loma Prieta earthquake. Bull Seismological Soc America. 1991;81:2143-66.

17. Noji EK. Medical and health care aspects of the Spitak-88 earthquake. In: Proceedings of the International Seminar on the Spitak-88 Earthquake, 23-26 May, 1989, Yerevan, S.S.R. of Armenia. Paris: UN Educational, Scientific and Cultural Organization; 1992. Pp. 241-6.

18. Noji EK. Acute renal failure in natural disasters. Ren Fail. 1992;14:245-9.

19. Eknoyan G. Acute renal failure in the Armenian earthquake. Kidney Int. 1993; 44:241-4.

20. Aznaurian AV, Haroutunian GM Atabekian AL Medical aspects of the consequences of earthquake in Armenia. In: Proceedings of the International Symposium on "Medical Aspects of Earthquake Consequences" in Yerevan Armenia, 9-11 October 1990. Yerevan, Armenia: Armenian Ministry of Health 1990. Pp. 9-10.

21. Frechette $\mathrm{CN}$. Rescuing earthquake victims in Armenia. Plast Reconstr Surg. 1989;84:838-40.

22. De Ville de Goyet C, Jeannee E. Epidemiological data on morbidity and mortality following the Guatemala earthquake. IRCS Medical Sciences. Soc Sci Med. 1976;4:212.

23. Alexander DE. Disease epidemiology and earthquake disaster: the example of Southern Italy after the Nov. 23rd, 1980 earthquake. Soc Sci Med. 1982;16: 1959-69.

24. Arvidson RM. On some mental effects of earthquakes [letter]. Am Psychol. 1969; 24:605-6.

25. Katsouyanni K, Kogevinas M, Trichopoulos D. Earthquake-related stress and cardiac mortality. Int J Epidemiol. 1986; 15:326-30

26. Trichopoulos D, Katsouyanni K, Zavitsanos X. Psychological stress and fatal heart attack: the Athens 1981 earthquake natural experiment. Lancet. 1983;1: 441-3.

27. Dobson AJ, Alexander HM, Malcolm JA Steele PL, Miles TA. Heart attacks and the Newcastle earthquake. Med J Aust. 1991;155:757-61.

28. Diaz de la Garza JA. Earthquake in Mexico, Sept 19 and 20 of 1985. Disaster Chronicles. No. 3. Washington, D.C.: Pan American Health Organization; 1987.

29. Noji EK, Kelen GD, Armenian HK, Oganessian A, Jones NP, Silverston KT. The 1988 earthquake in Soviet Armenia: a case study. Ann Emerg Med. 1990;19: 891-7.

30. Hingston RA, Hingston L. Respiratory injuries in earthquakes in Latin America in the 1970s: a personal experience in Peru, 1970; Nicaragua, 1972-73; and Guatemala, 1976. Disaster Med. 1983:1: 425-6.

31. Noji EK. Natural disasters. Crit Care Clin. 1991;7:271-92.
32. Showalter PS, Myers MF. Natural disasters in the United States as release agents of oil, chemicals, or radiological materials between 1980-1989: analysis and recommendations. Risk Anal. 1994; 14:169-82.

33. Noji EK. Training of search and rescue teams for structural collapse events: a multidisciplinary approach. In: Ohta M, Ukai T, Yamamoto Y, eds. New aspects of disaster medicine. Tokyo, Japan: Herusu Publishing Co., Inc.; 1989. Pp. 150-5.

34. Glass RI, Urrutia JJ, Sibony S, Smith $\mathrm{H}$, Garcia B, Rizzo L. Earthquake injuries related to housing in a Guatemalan village. Science. 1977; 197:638-43.

35. Noji EK. Medical consequences of earthquakes: coordinating medical and rescue response. Disaster Management. 1991;4:32-40.

36. Noji EK, Sivertson KT. Injury prevention in natural disasters: a theoretical framework. Disasters. 1987;11(4): 290-6.

37. Durkin ME, Thiel CC. Improving measures to reduce earthquake casualties. Earthquake Spectra. 1992;8:95-113.

38. National working group in Japan: tsunami protective measures in Japan. Tokyo: Tokyo University; 1961.

39. Schneider E. Northridge earthquake rapid health needs assessment of households-Los Angeles County, California. January 20, 1994. Atlanta: Centers for Disease Control and Prevention; 1994

40. Safar P. Resuscitation potentials in earthquakes. An international panel. Prehosp Disaster Med. 1987;3(2):77.

41. Degler RR, Hicks SM. The destruction of a medical center by earthquake: initial effects on patients and staff. Calif Med (now Western J Med). 1972;116:63-7.

42. Arnold C, Durkin M. Hospitals and the San Fernando earthquake of 1971: the operational experience. San Mateo, CA: Building Systems Development, Inc.; 1983.

43. Noji EK, Jones NP. Hospital preparedness for earthquakes. In: Tomasik KM, editor. Emergency preparedness: when the disaster strikes. Plant, Technology \& Safety Management Series. Oakbrook Terrace, IL: Joint Commission on the Accreditation of Health Care Organizations; 1990. Pp. 13-20.

44. Centers for Disease Control, U.S. Geological Survey, Office of US Foreign Disaster Assistance, National Science Foundation and Federal Emergency Management Agency. Proceedings of the First International Forum on Earthquake-Related Casualties, Madrid, Spain, July 1992. Reston, VA: U.S. Geological Survey; 1992.

45. Moorhead GV, Freeman C, Van Ness C. Injury patterns in a major earthquake. Sacramento, CA: Emergency Medical Services Authority, California; 1984.

46. Noji EK. Need for a sound research program on earthquake epidemiology. In: Hays WW, ed. Proceedings of a meeting of the U.S. working group on earthquake-related casualties. Reston, VA: U.S. Geological Survey; 1990. Pp. 71-80. (Open-file Report 90-244.) 